\title{
Anti Diabetic Plants-Overview
}

\author{
Suganthi A* \\ Department of Botany, Nirmala College for Women, India
}

Submission: December 09, 2017; Published: July 12, 2018

*Corresponding author: Suganthi A, Assistant Professor, Department of Botany, Nirmala College for Women, Coimbatore, Tamil Nadu, India, Tel: 9842182253; Email: suganthijrf@gmail.com

\section{Introduction}

Diabetes Mellitus (DM) is a leading cause of illness and death in developed countries and is epidemic in many developing and newly industrialized countries. Its macrovascular and microvascular complications are debilitating. The prevalence of diabetes in the world at all ages was estimated to be $2.8 \%$ in 2000 , and it is expected to approximate $4.4 \%$ in the year 2030 . The estimated global number of people of all ages and sex with diabetes in 2000 was 171 million. This is projected to increase to 366 million by 2030, with about 4 million deaths every year attributed to its complications. Recently, herbal medicines are gaining importance in the management of diabetes due to their high margin of safety. Here listed few antidiabetic plants recommended for pharmaceutical industry.

\section{Momordica charantia}

Momordica charantia (L.) family Cucurbitaceae (African cucumber) a medicinal plant used traditionally as an antidiabetic. Major active principles in M. charantia are sterols, triterpenes, glycosides notably momordin Ic, charantin, goyaglycosides, momordicosides and other cucurbitane glycosides, goyasaponins, the alkaloid momordicin, phenolic compounds, tannins, flavonoids, carotenoids and bioactive proteins like polypeptide $p$ and alpha-momorcharin [1]. The oleanane-glycoside momordin Ic and cucurbitane-type triterpenoid glycosides especially charantin and polypeptide $\mathrm{p}$ have been shown to have hypoglycaemic activity [2]. While Harazika et al. [3] have demonstrated that momordicilin a triterpene, is a potent inhibitor of glycogen synthase kinase-3, an enzyme involved in glucose homeostasis and potential target for anti-diabetic compound.

\section{Azardirachta indica}

It belongs to family meliaceae popularly known as Neem (English). It is commonly used plants in Africa traditional medicine for the management of diabetes mellitus. The hypoglycemic effect of this plant extract could be attributed to the presence of phytochemical constituents including, flavonoids, free and bound anthraquinones, tannins, terpenoids, sterols, saponins and alkaloids that have been associated with antidiabetic activity [4]. As reported by [5], flavonoids enhance lipogenesis and glucose transport in the adipocytes hence lowering blood sugar [4]. The alkaloids promotes the regeneration of pancreas islets thereby restoring insulin secretion [4]. Tannins and saponins have also been shown to have hypoglycemic activity [6]. Anthraquinones which have earlier been reported to lower blood glucose are used also in the treatment of peripheral neuropathy [7].

\section{Eugenia jambolana}

E. jambolana (Family: Myrtaceae) is well known for its antidiabetic potential. Jambolan is rich in compounds containing anthocyanins, glucoside, ellagic acid, isoquercetin, kaemferol and myrecetin. The seeds are claimed to contain alkaloid, jambosine, and glycoside jambolin or antimellin, which halts the diastatic conversion of starch into sugar and seed extract has lowered blood pressure by $34.6 \%$ and this action is attributed to the ellagic acid content [8].

\section{Phyllanthus emblica and Vaccinium oxycoccos}

Quercetin is one of the flavonoids found in the fruits of Phyllanthus emblica and Vaccinium oxycoccos. quercetin has potent antihyperglycemic drug properties [9].

\section{Citrus macroptera}

Citrus macroptera Montr (family-Rutaceae) commonly called Sat Kara (wild orange). Essential oil of fruit of Citrus maximally showed significant reduction of fasting blood glucose and hepatic glucose levels while hepatic glycogen significantly increased when compared to diabetic control animals [10].

\section{Cucurbit maxima}

C. maxima Duch (family: Cucurbitaceae) commonly known as pumpkin. The seeds show antidiabetic, anti-hyperlipidemic lowering both total cholesterol and triglyceride and at the same time increase HDL-cholesterol in STZ induced diabetic rats [11].

\section{Withania coagulans}

Withania coagulans Dunal (family: Solanaceae) commonly known as Indian cheese Maker. The fruits exhibited 


\section{Current Research in Diabetes \& Obesity Journal}

hypoglycaemic activity which is an effective and safe alternative treatment for diabetes [12].

\section{References}

1. Chaturvedi P (2012) Antidiabetic potentials of momordica charantia: Multiple mechanisms behind the effects. J Med Food 15(2): 101-107.

2. Lee SY, Eom SH, Kim YK, Park NI, Park SU (2009) Cucurbitane-type triterpenoids in momordica charantia Linn. J Med Plant Res 3(13): 1264-1269.

3. Hazarika R, Parida P, Neog B, Yadav RNS (2012) Binding energy calculation of GSK-3 protein of human against some anti-diabetic compounds of momordica charantia L (Bitter melon). Bioinformation 8(6): 251-254.

4. Elliot M, Chithan K, Theoharis CT (2000) The effects of plant flavanoids on mammalian cells: Implications for inflammation, heart disease and cancer. Pharmacological Reviews 52(4): 673-751.

5. Glauce SB, Ana Carolina CM, Ana Michelle RL, Kalyne AM, Tiago GV (2004) Hypoglycemic and anti-lipemic effects of the aqueous extract from cissus sicyoides. Biomedical Central Pharmacology 4: 9-12.

6. Sui DY, Lu ZZ, Li SH, Cai Y (1994) Hypoglycemic effect of saponin isolated from leaves of acanthopanax senticosus (Rupr. Et Maxin) Harms. Chung Kuo Chung Yao Tsa Chih 19: 683-685.

7. Broadhurst CL, Polansky MM, Anderson RA (2000) Insulin like biological activity of culinary and medicinal plant aqueous extracts in vitro. Journal of Agriculture and Food Chemistry 48(3): 849-852.

8. Morton J (1987) Fruits of warm climates. Julia Morton Winterville North Carolina, Miami, USA.

9. Paramaguru R, Mazumder PM, Sasmal D (2014) Antidiabetic activity of pterospermum acerifolium flowers and glucose uptake potential of bioactive fraction in L6 muscle cell lines with Its HPLC fingerprint Bio Med Resear Internat 2014: 1-10.

10. Peng CH, Ker YB, Weng CF, Peng CC, Huang CN, et al. (2009) Insulin secretagogue bioactivity of finger citron fruit (Citrus medica L. var Sarcodactylis Hort, Rutaceae). J Agric Food Chem 57(19): 8812-8819.

11. Ashok S, Ashish S, Tara C, Manoj K, Kailash (2013) Antidiabetic and antihyperlipidemic activity of cucurbitamaxima duchense (Pumpkin) seeds on streptozotocin induced diabetic rats. Journal of Pharmacognosy and Phytochemistry 1: 108.

12. Budhiraja RD, Sudhir S, Garga KN (1977) Pharmacological investigations on fruits of withania coagulans, dunal. Planta Med 32(2): 154-157.

\section{Your next submission with Juniper Publishers will reach you the below assets}

- Quality Editorial service

- Swift Peer Review

- Reprints availability

- E-prints Service

- Manuscript Podcast for convenient understanding

- Global attainment for your research

- Manuscript accessibility in different formats

( Pdf, E-pub, Full Text, Audio)

- Unceasing customer service

Track the below URL for one-step submission

https://juniperpublishers.com/online-submission.php 